\title{
Numerical Simulation of Thermoelastic Stress Analysis
}

Zuzana Stankovičová, Vladimír Dekýš, Pavol Novák, Milan Sapieta

Department of applied mechanics, Faculty of Mechanical Engineering, Univerzity of Žilina in Žilina. Unierzitná 1,010 26 Žilina. Slovak Republic. E-mail: zuzana.stankovicova@fstroj.uniza.sk, vladimir.dekys@fstroj.uniza.sk, pavol.novak@fstroj.uniza.sk, Milan.sapieta@fstroj.uniza.sk

This paper focuses on verification of experiment of thermoelastic stress analysis by using numerical solution. Thermoelastic stress analysis is noncontact technique to obtain thermograms, thermographic images of the stress fields, by using an infrared camera. In the elastic part experimental results can be used to determine the value of the first stress invariant under adiabatic conditions. The experimental part is dedicated to the postprocessing of the measured data. Numerical solution was performed by finite element method in two softwares: ANSYS and ABAQUS.

Keywords: numerical simulation, thermal stress analysis, stress filed, infrared camera

\section{Acknowledgement}

This work was supported by the Slovak Research and Development Agency under the contract No. APVV-0736-12.

\section{References}

[1] BOYCE, B. (1999). Steps to modern thermoelastic stress analysis, In conference: „ATEM konference, Ube, Japan, 1999“.

[2] SHARPE, W. (2005). Springer handbook of experimental solid mechanics, Springer, New York, 1095 p. ISBN 978-0-387-26883-5.

[3] BARTON, J. (1999). Introduction to thermoelastic stress analysis. In: Strain, Vol. 35, No. 2, pp. 35-40.

[4] RAJIC, N., ROWLANDS, D. (2013). Thermoelastic stress analysis with a compact low-cost mocrobolometer system. In: Quantitative infrared thermography journal, Vol. 10, No. 2, pp. 135-158.

[5] JAROSYEWICY, J., RADZISZEWSKI, L., DRAGUN, L. (2014). The study of the effect of static axial loads on vertically-mounted tapered cantilever transverse vibrations using the Cauchy function. In: Applied mechanics \& Materials, Vol.712, pp. 49-54.

[6] FLIR manual. Available online at www.flir.com

[7] BREITENSTEIN, O. (2010). Lock In thermography, Springer, New York, 2. edition, 253 p. ISBN: 978-3-642-02416-0.

[8] ŽMINDÁK, M., MEŠKO, J., PELAGIĆ, Z., ZRAK, A. (2014). Finite element analysis of crack growth in pipelines. In: Manufacturing technology, Vol. 14, No. 1, pp. 116-122.

[9] PELAGIĆ, Z., NÁGEL', M., ŽMINDÁK, M., RIECKY, D. (2015). Wear simulation modeling by using the finite element method. In: Manufacturing technology, Vol. 15, No.2, pp. 191-195.

[10] YANG, Z. et al. (2015). Design and implement of infrared thermography detection system excited by pulsed flash lamp. In: Manufacturing technology, Vol. 15, No.2, pp. 249-254.

[11]ŠUBA, O. et al. (2010). Modelling of transient thermal stress in layer walls. In: Manufacturing technology, Vol. 15 , No.2, pp. 16-19. 